\title{
The Cell Wall of Escherichia coli: Early Effects of Penicillin Treatment and Deprivation of Diaminopimelic Acid
}

\author{
By M. E. BAYER \\ Department of Molecular Biology, The Institute for Cancer Research, \\ Philadelphia, Pennsylvania 19111, U.S.A.
}

(Accepted for publication 31 August 1966)

\begin{abstract}
SUMMARY
The morphological effects on bacterial walls of the early stages of inhibition of mucopolymer synthesis have been investigated in Escherichia coli. Inhibition was achieved in strain B by penicillin treatment and in auxotrophic strains M 203 and M 173-25 by deprivation of diaminopimelic acid (DAP). Only growing organisms were affected; the walls of organisms in stationary phase remained unchanged. The first effects of treatment with penicillin appear in 20 min., whereas changes in DAP-deprived auxotrophs become visible only after $40-60 \mathrm{~min}$. The soft layers of the wall formed baglike protrusions and, at the same time, wide gaps or holes developed in the proteinaceous portion of the rigid layer. Widening of these gaps was paralleled by a weakening of the rigid layer, resulting eventually in bursting of the cell, or in protective media of high osmotic strength, in the formation of spheroplasts. The initial appearance and the subsequent widening of gaps in the rigid layer, observed almost exclusively in organisms multiplying logarithmically, are taken to indicate the presence of a mechanically weak mucopolymer formed under conditions that prevent crosslinking. The discontinuities, interpreted as sites of mucopolymer synthesis, were randomly distributed over the bacterium. Their appearance at the poles of the bacteria seemed frequently to be suppressed by media of high osmotic pressure, in which plasmolysis was first seen in the polar regions. The observations suggest that morphogenesis of the protein layer is dependent on the secondary structure of the mucopolymer in newly synthesized wall areas.
\end{abstract}

\section{INTRODUCTION}

The wall of Gram-negative bacteria consists of a multilayered structure (Glauert, 1962; Murray, 1962; Salton, 1964) which can be altered in its morphological properties by chemical or enzymic treatment as well as by growth inhibition (Liebermeister \& Kellenberger, 1956; Hofschneider, 1960; Murray, Steed \& Elson, 1965). In agreement with these reports are results of our own studies on the wall structure of Escherichia coli obtained with frozen-state microtomy. A general model of the organization of the cell wall has been proposed (Bayer \& Anderson, 1965) as follows. The innermost portion of the wall consists of a rigid mucopolymer which serves many functions: it provides the wall with the necessary strength to maintain the shape of the cell against the osmotic pressure of the cytoplasm (Mitchell \& Moyle, 1957); it is needed for priming its own synthesis (Lark \& Lark, 1961; McQuillen, 1960); it supports the soft outer lipid layers of the wall which are 'pasted' to it by non-covalent bonds (Weidel \& Pelzer, 1964). 
In an investigation of the wall structure of Escherichia coli (Bayer \& Anderson, 1965) it was shown that the rigid layer of the walls contained scattered gaps in an otherwise fairly uniform rigid layer. It was suggested that these gaps might represent the sites of growth, where autolytic enzymes had opened the wall structure to allow for synthesis of new wall elements. To achieve the introduction of a new building block (Park \& Strominger, 1957), the rigid structure has to be opened without endangering the mechanical stability of the whole wall. It can be assumed that such a loosening in the 'centres of growth' (Toennies \& Shockman, 1958) is caused by the action of several mucopeptide hydrolases (Pelzer, 1963).

After a new building block has been placed into the older rigid structure, the "weak point' is closed up, and the cell regains its former rigidity in that area. Any interference with the restoration will leave the rigid structure incomplete at the sites of synthesis. To achieve such an inhibition of wall synthesis and to observe parallel early alterations of the wall structure, we used penicillin, which is considered (Wise \& Park, 1965; Tipper \& Strominger, 1965) to block specifically the production of a rigid mucipolymer in the last steps of polymerization, the cross-linkage of the glycopeptides which is indispensable for the required mechanical stability of the polymer (Martin 1964). All previous steps in the synthesis of the wall-glycopeptides have been shown to be insensitive to penicillin (Anderson, Matsuhashi, Haskin \& Strominger, 1965) The production of larger amounts of defective mucopolymer will eventually lead to rupture of the whole wall of a growing bacterium. Because penicillin interferes with the synthesis of the wall, it affects growing bacteria only and remains ineffective against bacteria in the stationary phase. Interference with the cross-linkage of the mucopolymer can also be achieved in another way: by deprivation of diaminopimelic acid (DAP), an essential constituent of the mucopolymer in Escherichia coli (Weidel \& Primosigh, 1957) which is involved in the cross-linkage of neighbouring peptide side chains of the glucosaminopeptide (Wise \& Park, 1965; Tipper \& Strominger, 1965). Certain mutants of $E$. coli (e.g. M203 or M173/25) are unable to synthesize DAP and require for growth an external supply of this amino acid. When such an auxotrophic mutant is not given DAP, an un-crosslinked 'weak' mucopolymer is produced leading eventually to bursting of the bacterium or formation of a spheroplast.

In the present report we describe the early effects of penicillin treatment and DAPdeprivation on the structure of the wall of Escherichia coli. The dependence of the effects of penicillin on the state of growth and on the osmotic conditions of the cultures will be shown.

\section{METHODS}

Bacteria. Escherichia coli B, wild type, was obtained from Dr E. W. Six (State University of Iowa) and has been cultivated in our laboratories for several years. In $10 \mathrm{ml}$. amounts of $\mathrm{L}$ medium (see below), with aeration by bubbling of $150 \mathrm{ml}$. air $/ \mathrm{min}$. or by shaking, the generation time at $37^{\circ}$ in the log phase was $30 \mathrm{~min}$.

The auxotrophic mutant Escherichia coli M203, derived from E. coli W-ATCC 9637 by the penicillin method (Davis, 1949; Lederberg, \& Zinder, 1948) was kindly provided by Dr C. Gilvarg (Princeton University). This strain requires for growth to be given diaminopimelic acid. When grown without aeration in $10 \mathrm{ml}$. minimal medium (Davis \& Mingioli, 1950) +diaminopimelic acid+lysine, its generation time was 100 min.; aeration by shaking and with yeast extract added to the same medium 
decreased the generation time to $30 \mathrm{~min}$. Cultures of $E$. coli м 203 in medium containing yeast extract +lysine, but without DAP, showed about a twofold increase in optical counts for the first $30 \mathrm{~min}$., then a decreasing count for the remaining time of the experiment.

Another DAP-requiring mutant of Escherichia coli M 173-25, was kindly provided by Dr B. D. Davis (Harvard Medical School, Boston), and was grown as described for mutant м203.

Culture media. L medium consisted of $(\%, w / v): 1$, Bacto-tryptone (Difco Laboratories, Detroit, Mich.); $0 \cdot 5$, yeast extract (Difco); $0 \cdot 5, \mathrm{NaCl} ; 0 \cdot 1$, glucose; adjusted to $\mathrm{pH} 7 \cdot 0$ with $\mathrm{N}-\mathrm{NaOH}$.

For growth of mutant M203, $20 \mu \mathrm{g} . \alpha-\epsilon$-DL-diaminopimelic acid (DAP) (Cyclo Chemical Co., Los Angeles, Calif.) $+20 \mu \mathrm{g}$. of L-lysine (Calbiochem, Los Angeles, Calif.) were added $/ \mathrm{ml}$. minimal medium. To most of our cultures yeast extract (Difco), $500 \mu \mathrm{g} . / \mathrm{ml}$., was added.

For osmotic protection the S-P medium of Hirokawa (1962) was used with a slightly lower sucrose concentration ( $18 \%$ instead of $20 \%$ ).

Procedures. The bacteria were counted in Neubauer chambers with a phase microscope. When the number of bacteria reached between $6 \times 10^{7} / \mathrm{ml}$. and $2 \times 10^{8} / \mathrm{ml}$. they were pelletted at $4000 \mathrm{rev} . / \mathrm{min}$. in a Servall centrifuge at $4^{\circ}$ for $15 \mathrm{~min}$., and the pellet stored at $1^{\circ}$ in a moist atmosphere. A portion of each culture was grown for $6-8 \mathrm{hr}$ longer, reaching optical counts of $5 \times 10^{9} / \mathrm{ml}$. and more. The bacteria were then collected in pellets as described above.

The maximum loss of viability of logarithmically growing bacteria after pelleting and resuspending was about $15 \%$, as tested by colony-counting on $\mathrm{L}$ medium agar after incubation for $12 \mathrm{hr}$ at $37^{\circ}$.

When suspensions of Escherichia coli в and E. coli м203 were to be treated with penicillin, they were first pelleted, and the pellets then resuspended in $\mathrm{L}$ medium containing $20 \mathrm{~g}$. sucrose and $0.2 \mathrm{~g}$. anhydrous $\mathrm{MgSO}_{4}$ per $100 \mathrm{ml}$. of total fluid. Sucrose and $\mathrm{MgSO}_{4}$ provide the osmotic stabilization of spheroplasts (Hirokawa, 1962). To stationary phase cultures appropriate amounts of solid sucrose and anhydrous $\mathrm{MgSO}_{4}$ were added.

Potassium penicillin G (Abbott Laboratories, Chicago, Ill.) was added to a final concentration of $10^{3}$ units $/ \mathrm{ml}$. After 20-30 min. the bacterial suspensions were rapidly cooled and pelleted at $6000 \mathrm{rev} . / \mathrm{min}$. for $20 \mathrm{~min}$. at $4^{\circ}$.

To exclude the plasmolyzing effects of the sucrose, some of the suspensions were treated with penicillin in media of the same composition, but without sucrose, When the optical counts of the bacteria in cultures of the mutants $E$. coli M203 and M 173-25 had reached $6 \times 10^{7} / \mathrm{ml}$. the bacteria were pelleted as described above. The pellets were resuspended in minimal medium containing yeast extract, lysine and sucrose, but lacking DAP. After incubation at $35^{\circ}$ for $60-120 \mathrm{~min}$. and gentle shaking, the cultures were pelleted at $6000 \mathrm{rev} . / \mathrm{min}$. and the pellet stored at $1^{\circ}$.

To study the walls of dead bacteria, cultures of logarithmically growing Escherichia coli B were heat-treated at $67^{\circ}$ for $10 \mathrm{~min}$. in L medium and rapidly cooled in water at 5 to $7^{\circ}$. Only 1 out of $2 \times 10^{4}$ bacteria remained viable when plated on $L$ medium agar and incubated at $37^{\circ}$. The pellets were obtained as described above.

Our technique for microtomy in the frozen state (Bayer \& Anderson, 1965) began with quick freezing of small portions of the unfixed bacterial pellets in liquid nitrogen. 
The frozen bacteria were opened by the knife of an ultramicrotome at $-30^{\circ}$, and the cytoplasm allowed to escape during a subsequent brief washing with distilled water at room temperature. The remaining cell walls were then stained negatively in silicotungstate, $\mathrm{pH} 6.5$. When treated with $0.5 \%$ (w/v) sodium dodecyl sulphate (SDS) on the electron microscope grid, the lipid layers of the cell walls dissolved. A period of $5 \mathrm{~min}$. at $20^{\circ}$ was sufficient to remove the lipids in Escherichia coli в walls, whereas walls of E. coli M 203 and M 173-25 needed treatment for $12 \mathrm{hr}$ at $45^{\circ}$. After a subsequent washing in distilled water for $20 \mathrm{sec}$., the wall residues were negatively stained and immediately dried inside the microscope. Electron micrographs were taken with a Siemens Elmiskop I equipped with double condenser at magnifications of $\times 20,000$ and 40,000. Light microscope observations and photomicrographs were made with a Zeiss GFL microscope, equipped with a phase-contrast oil-immersion objective (N.A. $1 \cdot 25)$ and condenser and Zeiss electronic microflash.

\section{RESULTS}

\section{Phase-contrast microscopy}

The size and shape of Escherichia coli organisms depend on the growth phase. Logarithmically growing bacteria are rod-shaped and measure $1 \cdot 5-2 \mu$ in length and $0 \cdot 5-1 \mu$ in width, with an axial ratio of 2 or more (Pl. 1, fig. 1). Stationary phase bacteria are smaller and measure slightly more than $1 \mu$ in length with an axial ratio of about $\mathbf{1 \cdot 5}$. In both types of cultures, however, one finds occasionally very long rodshaped bacteria.

The effects of sucrose concentrations of $18-20 \%(\mathrm{w} / \mathrm{v})$ on the protoplasmic contents of Escherichia coli B can easily be observed in the light microscope: plasmolysis becomes visible immediately after exposing the cultures to the sucrose. Usually the protoplast seems to be retracted from one or both poles of the cell (Pl. 1, figs. 2, 3); occasionally also other portions of the protoplasm are involved. Transfer of such bacteria to a medium of normal osmotic pressure quickly reverses the plasmolysis. Continued exposure to $18 \%(\mathrm{w} / \mathrm{v})$ sucrose results in gradual reversal of the plasmolysis; after incubation for 10-15 min., most of the protoplasts seem to occupy again the entire space inside the walls. The multiplication (generation) time seems to be prolonged during the reversal in sucrose and returns to its former value after about 20-30 min. This effect might be caused by the sucrose or by the disturbance of growth during pelleting and resuspension.

The effects of penicillin become visible after $20 \mathrm{~min}$., while DAP-deprival did not produce any noticeable effects until growth had proceeded for 45-60 min. In both instances the changes consisted of a swelling of the bacteria, followed by the appearance of hernia-like extrusions of the wall; some of these extrusions measured up to $1 \mu$ in length (P1. 1, figs. 4-6). In later stages during either treatment the extruding cytoplasmic contents form large spherical bodies, frequently with portions of the walls still attached to them (Lederberg, 1956; Liebermeister \& Kellenberger, 1956). Bacteria without sucrose protection seem either to burst very suddenly or to leak at many small areas of their wall simultaneously, thus frequently obscuring observation with the light microscope of the site of burst. Finally, 2 or $3 \mathrm{hr}$. later, the bacteria became spheroplasts in the penicillin-treated series. The later stages differed somewhat among the strains. 
In DAP-deprived cultures of Escherichia coli M 203 many bacteria became rather long ( $5 \mu$ and more) and seemed to form extrusions less frequently; instead, they were often blown up to bottle- and spindle-shaped forms (Pl. 4, fig. 12). The phenomenon could usually be observed in the central portions of the bacterium, less frequently at the poles or at zones where the cytoplasm had retracted from the wall. After $E$. coli M 173-25 was deprived of DAP for 60-90 min., most of the swollen bacteria had gradually rounded up and formed spherical spheroplasts without bursting. Only occasionally were longer forms $(3-4 \mu)$ found, some of them with asymmetrical deformations. Formations of spheroplasts remained incomplete in DAP-deprived cultures of $E$. coli $\mathbf{M} 203$, even after prolonged incubation ( $4 \mathrm{hr}$.); furthermore, long forms were observed with irregularities in their form of growth; branching, Y-shaped forms were frequently found.

\section{Electron microscopy}

Negative staining of whole bacteria in the electron microscope confirmed the light microscope results about the size and shape of Escherichia coli. The surfaces of bacteria in logarithmic and in stationary phases looked similar.

The application of frozen-state microtomy (Bayer \& Anderson, 1965) yielded no apparent difference between Escherichia coli B and E. coli м203 except that the latter seemed to be more vulnerable to mechanical injury. The structures rendered visible by this technique represent mainly the two outer layers with their channels and small protrusions (Pl. 1, fig. 7). The particulate protein of the rigid layer became visible after removal of the lipoprotein and lipopolysaccharide from the walls with sodium dodecyl sulphate (Pl. 2, figs. 8, 9), while the mucopolymer seemed to remain invisible in negatively stained preparations. The rigid layer contained gaps and holes (100-200 $\AA$ ) in the otherwise uniform distribution of its proteinaceous cover (Pl. 2, fig. 9). The number of discontinuities depended on the state of growth: almost all bacteria in the logarithmic phase showed numerous gaps (Pl. 2, fig. 9), whereas in stationary-phase bacteria gaps and holes were very rare. Untreated stationary-phase bacteria resembled closely the example in P1. 2, fig. 8 in this respect. The distribution of the gaps seemed to be random.

Heat-killed bacteria exhibited gaps to the same extent and with the same distribution as did unheated controls; this seems to exclude the possibility that the gaps were formed by the action of autolytic enzymes during preparation (Weidel, Frank \& Leutgeb, 1963).

The proteinaceous cover is composed of particles which were better defined in cell walls of stationary bacteria than in the walls of logarithmically growing bacteria (compare Pl. 2, figs. 8, 9). In both phases of a culture the smallest ball-shaped protein units in the rigid layer of the cell walls measured from 50 to $70 \AA$ in diameter and frequently contained a less compact or possibly hollow centre, filled with the staining material (Pl. 2, fig. 8, arrows). This property was not affected by the penicillin treatment.

The effects of penicillin become visible only in logarithmically growing bacteria; no effect was observed on the walls of stationary-phase bacteria. In agreement with the light microscope observations, the first effects on the walls showed up after the bacteria had been exposed to penicillin for 15-20 min. They consisted of bag-shaped extrusions of the walls, occasionally rather large in size and frequently including portions of cytoplasmic membrane. In other organisms the wall was buckled out at 
numerous small areas (Pl. 3, fig. 10); the visible wall structure seemed still to be continuous in these locations. Increasing time of penicillin treatment (to about $30 \mathrm{~min}$.) caused drastic changes in the walls of most of the bacteria: the channels disappeared, the contour of the walls became lobulate and the surface appeared to be made of large round or oval patches. The rigidity of the walls decreased and the bacteria assumed a round or oval shape. In the final stages, and probably as a result of mechanical injury, the walls disintegrated into scattered circular discs of different sizes. The cytoplasmic membrane was visible inside the walls as a lighter grey structure with a continuous outline (P1. 1, fig. 7; Pl. 3, fig. 10; Pl. 4, fig. 13). The outer zone was slightly brighter than the other portions and measured about $70 \AA$ in width in penicillin-treated bacteria as well as in the control organisms. This value is in agreement with the thickness of cytoplasmic membranes in general.

When the lipid layers of bacteria treated with penicillin were removed, a considerable widening of the dark gaps and holes in the remaining rigid layer was observed (P1. 3, fig. 11). The total number of gaps did not seem to increase as compared with untreated bacteria under similar growth conditions. In general, the widening of the discontinuities was randomly distributed over the entire wall residue. Sometimes, however, the poles of the walls appeared to be excluded or seemed less affected by this phenomenon than were the other portions of the wall (Pl. 5, fig. 15), an effect most commonly observed in bacteria growing in media which contained 18-20\% sucrose. Penicillin treatment without sucrose protection caused a much more even distribution of the wall alterations, including those in the polar regions. Finally the widening discontinuities formed a network separating the 'older' portions of the rigid layer from one another (Pl. 5, fig. 15). Among the rigid residues occasionally circular or lobulate pieces with a central hole of 200-700 $\AA$ diameter were found (P1. 3, fig. 11, enclosed in squares). The outside dimensions of these pieces varied from 800 to $1500 \AA$ and fragments were found scattered all over the supporting film. They were originally covered by the lipid material of the wall, and provided the disc-shaped elements of the distintegrating wall with their rigid 'skeleton'. However, not all of the discs of disintegrating walls are necessarily equipped with a piece of rigid mucopolymer, since lipopolysaccharides extracted from walls spontaneously form sheets (Weidel, Frank \& Martin, 1960) and discs (Bladen \& Mergenhagen, 1964).

The alterations in the walls of the auxotrophic mutants Escherichia coli M203 and M173-25 after DAP-deprivation consisted of a large increase in the amount of soft lipid material which protruded from the walls in cloud-like patterns (Pl. 4, fig. 13). These clouds emerged from small localized areas on the wall. As in the penicillintreated bacteria, DAP-deprivation of the auxotrophic mutants caused in the rigid layer a considerable increase of 'darker' areas (discontinuities) at the expense of the 'old' mucopolymer. As compared with the effects of penicillin, however, the following differences were observed: (1) the rigid layer of mutant M203 disintegrated into more numerous, smaller patches; (2) the gaps in the walls of DAP-deprived mutant M203 seemed not to be widened by stretching of the cell wall by osmotic forces: the gaps were no wider in the extended regions of spindle-shaped bacteria than in the less deformed or normal sized regions. An explanation may be sought in the slight 'leakage' of the м203 mutant (Dr C. Gilvarg, personal communication) which might provide for a low repair rate, a rate low enough to be initially overcome by osmotic forces, but eventually rapid enough to prevent bursting or even expansion to complete sphero- 
plasts. DAP-deprived mutant $\mathrm{M} 173-25$ (which is not leaky) frequently showed a rigid layer which had a strong resemblance to the rigid layer of bacteria treated with penicillin.

\section{DISCUSSION}

Immunological studies of the pattern of synthesis of the surface antigens in Gramnegative bacteria have yielded support for the assumption of scattered growth zones in the outer layers of the wall (May, 1963; Cole, 1964; Beachey \& Cole, 1966). However, firm conclusions about the growth of the rigid layer cannot be drawn from immunological reactions alone; the mucopolymer is apparently not exposed on the outside of the cell. Furthermore, it is not known how firm are the bonds between the soft lipid outer coat and the rigid layer (Rogers, 1965), thus raising the problem of lateral mobility of the antigenic soft material on the surface.

The relation between the lipid layers and the rigid mucopolymer seems to be altered by interference with the synthesis of the mucopolymer, especially after DAP-deprival of the auxotrophic mutants of Escherichia coli. The hernia-like extrusions visible in the early stages of penicillin treatment can be explained sufficiently by a relative increase of the osmotic pressure inside the wall when the bacteria are in an environment of lower osmotic pressure. In favour of this view is the fact that we occasionally found the cytoplasmic membrane driven into such an outpocketing. In DAP-deprived bacteria, however, a different mechanism has to be found to interpret the formation of the large amounts of soft material which protrudes from the wall with no deformation of the cytoplasmic membrane. One may tentatively assume that the rate of synthesis of the mucopolymer is decreased relative to the synthesis of wall lipids. Such a disproportionate growth would result in the accumulation of excess 'soft' material outside the bacterium.

The synthesis of the mucopolymer in Escherichia coli has been followed by using radioactive DAP (van Tubergen \& Setlov, 1961). Their results indicated that the rigid layer contained many, more or less randomly scattered, synthesizing 'centres'; the label of the wall of the parent bacterium had been 'randomly' inherited in at least 200 fragments to the daughters.

If one assumes that the rigid layer has been opened at the gaps we observed in log-phase bacteria to allow for new synthesis, this synthesis would indeed seem to occur at many randomly scattered places. That autolytic processes produce a similar morphological pattern on the rigid layer was shown by Weidel et al. (1963) in autolytically damaged bacteria where wide zones free from the particulate proteinaceous layer appeared on the wall residues. The function of the proteinaceous particles which cover the mucopolymer is unknown. They are best defined and most evenly distributed in the walls of bacteria in stationary-phase cultures. On the other hand, they seem to disappear completely as morphological entities in certain L-forms of Proteus mirabilis. Martin (1964) therefore suggested that this protein in its particulate form might have an important function in the morphogenesis of the rigid mucopolymer. Our results suggest a more subtle interaction; for after penicillin treatment, when cross-linkage is prevented, the newly synthesized portions of the mucopolymer layer lack a layer of proteinaceous particles, indicating that the deposition of the protein as particles might depend on the conformation of the mucoprotein.

Murray et al. (1965) found that bacterial walls (Escherichia coli and some other 
Gram-negative bacteria) lost about $20-35 \AA$ of their thickness after penicillin-induced spheroplast formation; an even greater loss could be accounted for by the disappearance of the particulate protein. Taking the presence of proteinaceous particles to indicate an undisturbed rigid layer, we interpret the gaps normally found in this layer as sites where the mucopolymer had been temporarily opened to allow the introduction of new building blocks into the growing wall. The wider gaps in penicillin-treated bacteria as well as in the DAP-deprived mutants might represent locations where cross-linkage was not sufficiently achieved during an appreciable fraction of the growth period.

The distribution of the gaps in the wall of a penicillin-treated Escherichia coli organism seemed in most cases to be random, especially in the cylindrical part of the wall. In some of the bacteria, however, portions of the walls, predominantly the poles, were less affected or even completely free from lesions. Widened gaps were then found in the central portions of the cell wall, where the wall finally burst, a sequence of events which was followed frequently with the phase-contrast microscope. Also the formation of spindle-shaped cells after DAP-deprivation of the auxotrophic mutants can be explained by an initial disproportionate weakening of the central or cylindrical portions of the walls, the zones which contain the sites where the new cell boundary will be formed.

Assuming that the presence of the cell membrane is necessary for the action of hydrolysing and polymerizing enzymes, one can tentatively attribute uneven distribution of the widened gaps to uneven plasmolytic retraction of cell membrane from cell wall, e.g. in sucrose solutions. The action of enzymes would then be decreased or even interrupted at those areas of the walls where the cytoplasm had been retracted. When the plasmolysing effect of sucrose was not operative, a more even distribution of the lesions was achieved, including at the poles of the cell walls. It is of interest that the surface antigens at the poles of Escherichia coli seem to be less involved in synthesis than do other portions of the wall (Beachey \& Cole, 1966). Under normal growth conditions, a less firm contact of wall and membrane at the cell poles might be involved in this phenomenon; plasmolysis is first detectable there. However, there might well be other factors involved in the exclusion of certain areas of the wall from such phenomena as formation of widened gaps after inhibition of mucopolymer synthesis. The possibility has to be considered of localized signals for the division of the cell wall from the bacterial DNA via the cell membrane. This might include an increase in synthesis and transport of mucolytic enzymes to the sites of intensified 'modelling' of wall material during division (Rogers, 1965).

I wish to thank Drs T. F. Anderson, Irene Diller and G. T. Rudkin for their valuable suggestions and their help in preparing the manuscript, $\mathrm{Dr} \mathrm{B}$. D. Davis and Dr C. Gilvarg for providing us with the auxotrophic mutants of Escherichia coli, and Miss Catherine Cienkowski for her technical assistance. This work was supported by grants GB-982 and GB-4640 from the U.S. National Science Foundation and CA-06927 from the U.S. Public Health Service. 


\section{REFERENCES}

Anderson, J. S., Matsuhashi, M., Haskin, M. A. \& Strominger, J. L. (1965). Lipid-phosphoacetyl muramyl-pentapeptide and lipid-phosphodisaccharide-pentapeptide: presumed membrane transport intermediates in cell wall synthesis. Proc. natn. Acad. Sci., U.S.A. 53, 881.

BAYER, M. E. \& ANDerson, T. F. (1965). The surface structure of Escherichia coli. Proc. natn. Acad. Sci., U.S.A. 54, 1592.

BEACHEY, E. H. \& Cole, R. M. (1966). Cell wall replication in Escherichia coli. Abstr. 66, Ann. Meeting Am. Soc. Microbiol., Los Angeles.

Bladen, H. A. \& Mergenhagen, S. E. (1964). Ulstrastructure of Veillonella and morphological correlation of an outer membrane with particles associated with endotoxic activity. J. Bact. 88, 1482.

Cole, R. M. (1964). Cell wall replication in Salmonella typhosa. Science 143, 820.

DAvis, B. D. (1949). The isolation of biochemically deficient mutants of bacteria by means of penicillin Proc. natn. Acad. Sci., U.S.A. 35, 1.

Davis, B. D. \& Mingioli, E. S. (1950). Mutants of Escherichia coli requiring methionine or vitamin B 12. J. Bact. 60, 17.

Glauert, A. M. (1962). Fine structure of bacteria. Br. med. Bull. 18, 245.

Hirokawa, H. (1962). Biochemical and cytological observations during the reversing process from spheroplasts to rod-form cells in Escherichia coli. J. Bact. 84, 1161.

HofsChnemer, P. H. (1950). Zur Wandstruktur von Escherichia coli B Spheroplasten. Proc. Eur. Reg. Conf. Electron Microscopy, Delft 2, 1028.

LARK, K. G. \& LARK, C. (1961). Studies on the mechanism by which D-amino acids block cell wall synthesis. Biochim. biophys. Acta 49, 308.

Lederberg, J. (1956). Bacterial protoplasts induced by penicillin. Proc. natn. Acad. Sci., U.S.A. 42, 574.

LEDERBERG, J. \& ZINDER, N. (1948). Concentration of biochemical mutants of bacteria with penicillin. J. Am. chem. Soc. 70, 4267.

Liebermeister K. \& Kellenberger, E. (1956). Studien zur L-form der Bakterien. $Z$. Naturf. 11 b, 200.

Martin, H. H. (1964). Composition of the mucopolymer in cell walls of the unstable and stable L-form in Proteus mirabilis. J. gen. Microbiol. 36, 441.

MAY, J. W. (1963). The distribution of cell wall label during growth and division of Salmonella typhimurium. Exp. Cell Res. 31, 217.

MCQUILlen, K. (1960). Bacterial protoplasts. In The Bacteria. Vol. I. Structure. Ed. by I. C. Gunsalus and R. Y. Stainer. New York: Academic Press.

Mrtchell, P. \& Moyle, J. (1957). Autolytic release and osmotic pressure of 'protoplasts' from Staphylococcus aureus. J. gen. Microbiol. 16, 184.

MurRAY, R. G. E. (1962). Fine structure and taxonomy of bacteria. In Microbial Classification. Symp. Soc. gen. Microbiol. 12, 119.

Murray, G. E., Steed, P. \& Elson, H. E. (1965). The location of the mucopeptide in sections of the cell wall of Escherichia coli and other Gram-negative bacteria. Can. J. Microbiol. 11, 547.

Park, J. T. \& Strominger, J. L. (1957). Mode of action of penicillin. Science 125, 99.

Pelzer, H. (1963). Mucopeptidhydrolasen in Escherichia coli B. $Z$. Naturf. $18 b, 950$.

Rogers, H. G. (1965). The outer layers of bacteria. In Function and Structure of Microorganisms. Symp. Soc. gen. Microbiol. 15, 186. Cambridge University Press.

Salton, M. R. J. (1964). The Bacterial Cell Wall. Amsterdam: Elsevier Publishing Company.

TIPPER, D. J. \& Strominger, J. L. (1965). Mechanism of action of penicillins: a proposal based on their structural similarity to acyl-D-alanyl-D-alanine. Proc. natn. Acad. Sci., U.S.A. 54, 1133.

Toennies, G. \& Shockman, G. D. (1958). Growth chemistry of Streptococcus faecalis. IV Colloquium Intern. Congr. Biochem., Vienna, p. 365.

van Tubergen, R. P. \& Setlow, R. B. (1961). Quantitative radioautographic studies on exponentially growing cultures of Escherichia coli. Biophys. J. 1, 589.

Weidel, W., Frank, H. \& Leutgeb, W. (1963). Autolytic enzymes as a source of error in the preparation and study of Gram-negative cell walls. J. gen. Microbiol. 30, 127.

WeIdel, W., Frank, H. \& MARTIN, H. H. (1960). The rigid layer of the cell wall of Escherichia coli strain B. J. gen. Microbiol. 22, 158.

WeIdel, W. \& Pelzer, H. (1964). Bag shaped macromolecules, a new outlook on bacterial cell walls. Adv. Enzymol. 26, 193.

Weidel, W. \& Primosigh, J. (1957). Die gemeinsame Wurzel der Lyse von Escherichia coli durch Penicillin oder durch Phagen. Z. Naturf. $12 b, 421$.

Wise, E. M., Jun. \& PARK, J. T. (1965). Penicillin: its basic site of action as an inhibitor of a peptide cross-linking reaction in cell wall mucopeptide synthesis. Proc. natn. Acad. Sci., U.S.A. 54, 75. 


\section{EXPLANATION OF PLATES}

Plate 1

Figs. 1-6. Phase-contrast micrographs, magnification $\times 3300$. The bar equals $3 \mu$.

Fig. 1. Escherichia coli B from a culture growing logarithmically in $\mathrm{L}$ medium.

Figs. 2, 3. $E$. coli B, shortly after transfer to $\mathrm{L}$ medium containing $18 \%(\mathrm{w} / \mathrm{v})$ sucrose. The cytoplasm is retracted from the wall mainly at the poles of the bacteria (compare P1. 5, fig. 15).

Figs. 4-6. E. coli B after $20 \mathrm{~min}$. penicillin treatment in L medium. Some of the bacteria have developed extrusions of the wall.

Fig. 7. Electron micrograph showing channel-like structures in the wall of $E$. coli $\mathrm{M} 203$ grown in the presence of diaminopimelic acid. $\times 100,000$.

\section{Plate 2}

Rigid layer of Escherichia coli B, magnification $\times 100,000$.

In all the electron micrographs except P1. 5, the bar represents $0 \cdot 2 \mu$.

Fig. 8. Stationary phase, after treatment with penicillin in $L$ medium with $18 \%(w / v)$ sucrose for $20 \mathrm{~min}$. The arrows point to ball-shaped particles with 'hollow' centres.

Fig. 9. Logarithmic phase, without penicillin or sucrose.

\section{Plate 3}

Escherichia coli B after penicillin treatment of a culture growing logarithmically in $\mathrm{L}$ medium without sucrose, magnification $\times 100,000$.

Fig. 10. Cell wall with numerous extrusions of the non-rigid portions of the wall.

Fig. 11. Rigid layer of such a wall showing wide gaps and holes in the proteinaceous cover of the mucopolymer. Two of the zones are enclosed in squares where wall components are separated into circular or lobular elements containing a central hole.

\section{Plate 4}

Escherichia coli auxotrophic mutant $\mathrm{M} 203$

Fig. 12. After DAP-deprivation for $3 \mathrm{hr}$.; phase contrast; $\times 3300$.

Fig. 13. Cell wall of an organism from the same culture; electron micrograph; $\times 100,000$.

Fig. 14. Rigid layer of the wall of another organism from the same culture, revealed by extraction with sodium dodecyl sulphate; $\times 100,000$.

\section{Plate 5}

Fig. 15. Wall of Escherichia coli B, logarithmic phase, after penicillin treatment for 20 min. in $\mathrm{L}$ medium containing $18 \%(\mathrm{w} / \mathrm{v})$ sucrose; $\times 48,000$. The bar represents $0.5 \mu$. Gaps and holes are suppressed in the polar regions (compare Pl. 1, figs. 2, 3). 
Journal of General Microbiology, Vol. 46 , No. 2

Plate 1

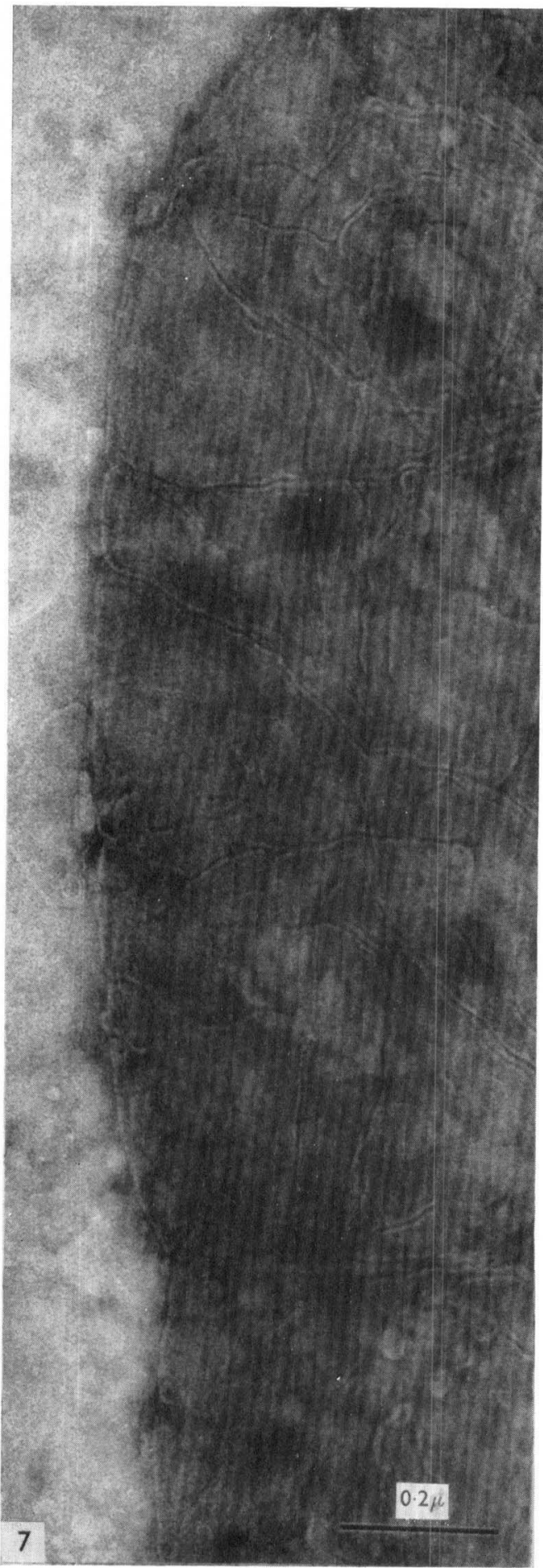

M. E. BAYER
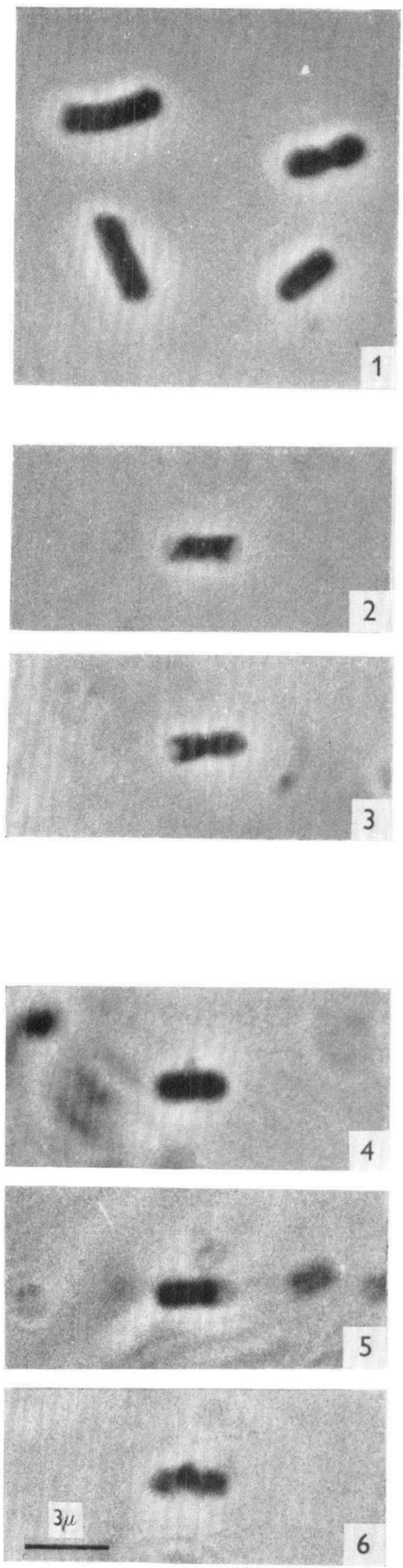

(Facing p. 246) 
Journal of General Microbiology, Vol. 46, No. 2

Plate 2
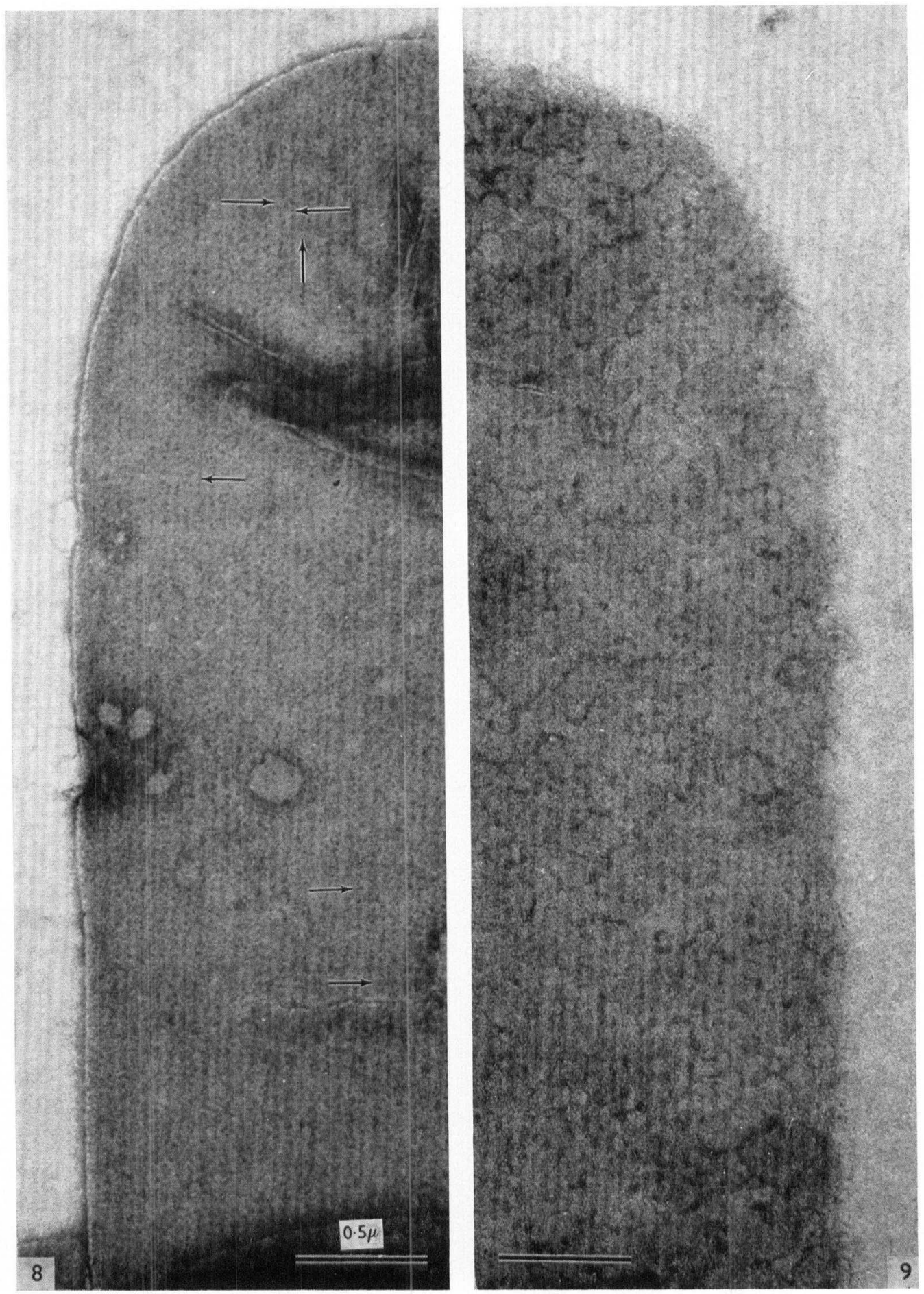

M. E BAYER 
Journal of General Microbiology, Vol. 46, No. 2

Plate 3
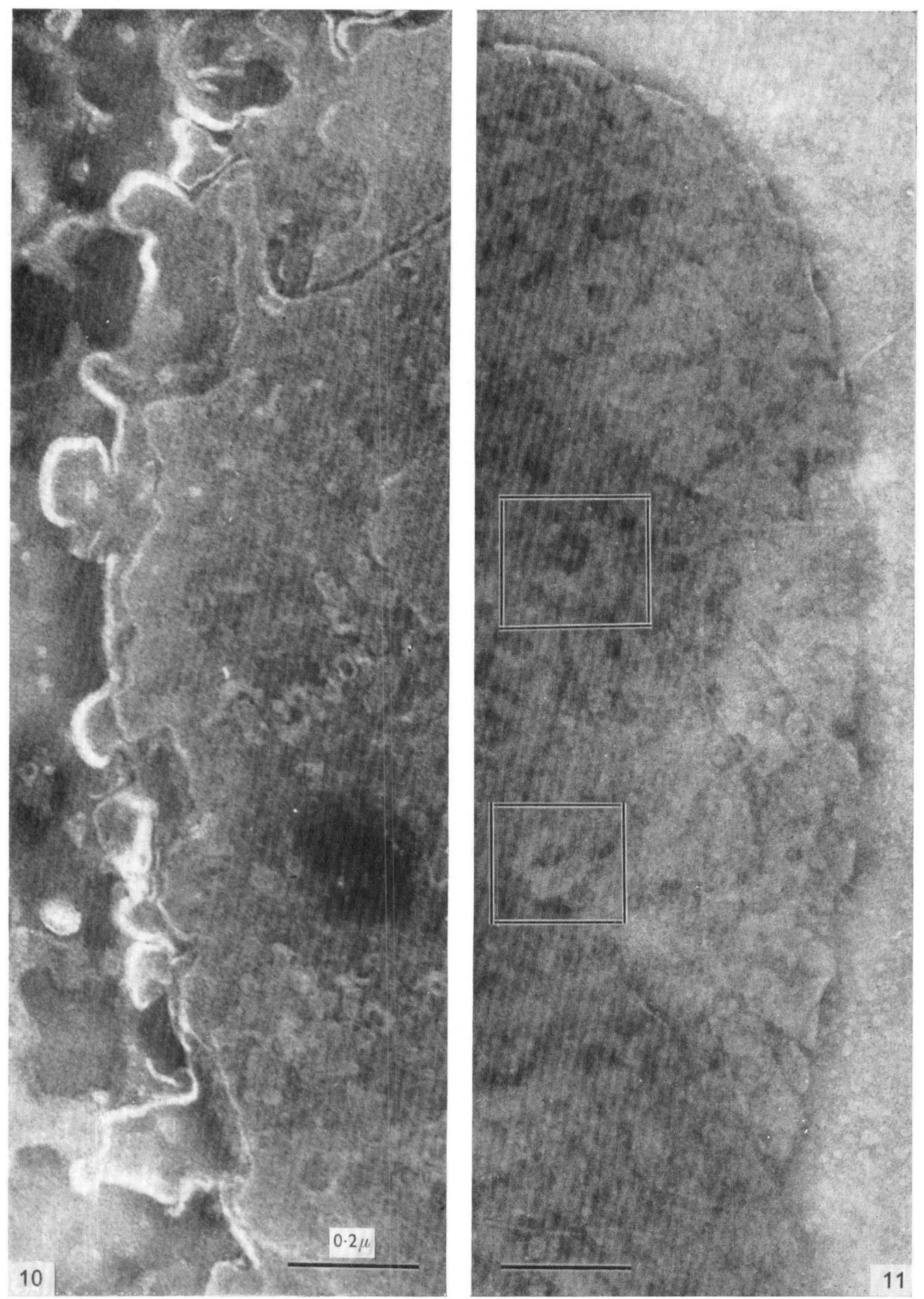

M. E. BAYER 
Journal of General Microbiology, Vol. 46, No. 2

Plate 4
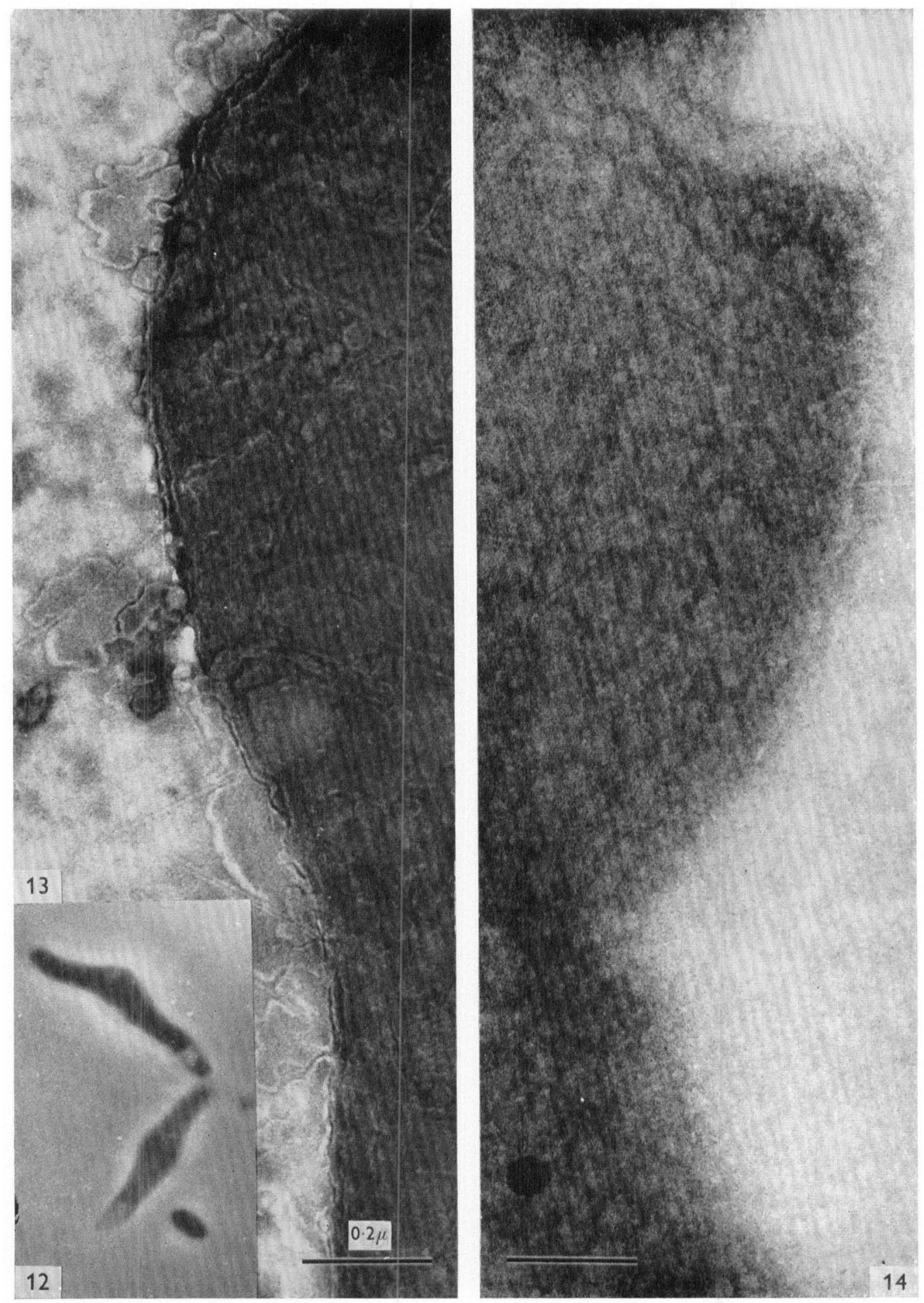

M. E. BAYER 
Journal of General Microbiology, Vol. 46, No. 2

Plate 5

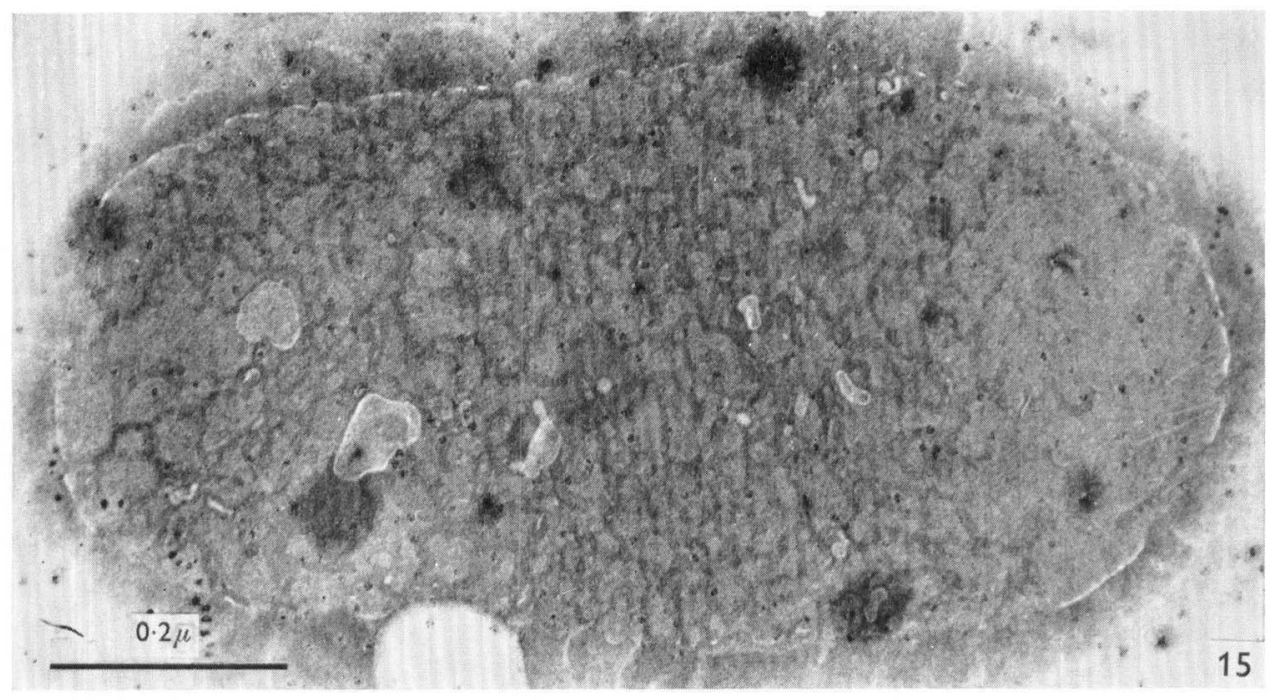

M. E. BAYER 